\title{
How much is a donkey worth?
}

\section{Qual o valor do jumento?}

\author{
Thereza Cristina Bório dos Santos Calmon de Bittencourt ${ }^{1}$ (D); Edna Maria da Silva ${ }^{1}$; \\ Chiara Albano de Araujo Oliveira ${ }^{1}$
}

\begin{abstract}
${ }^{1}$ Universidade Federal da Bahia, Escola de Medicina Veterinária e Zootecnia, Departamento de Medicina Veterinária Preventiva e Produção
\end{abstract} Animal, Salvador - BA, Brasil

\begin{abstract}
This study aimed to estimate the donkey unit cost of production and to contextualize it with the socio-economic condition of the Brazilian semiarid region. A study model was proposed in which the costs of maintenance and animal production were considered, assuming that the herd already existed on the property and the use of the available facilities. The production cycle of donkeys was estimated at 36 months, with an initial herd of 100 jennies and five jacks. For the estimation of forage production, native pastures to the semi-arid region were considered. The unit cost of production was estimated for donkey US\$258.00/year. However, when the donkey is integrated into the production unit of the family farming system, this animal should be considered as a production asset (draught, pack, and ridden). In face of the growing demand for donkey hide in the international market, the absence of public policies for the protection and welfare of these animals, and even considering the possibility of integrating them into family farming systems, the following question must be asked: how long before Northeast donkeys are extinct? Estimating the unit cost of donkey production and considering them as an essential production asset in family farming could be a starting point to diminish their abandonment in several communities and the consequences of the exploitation of hides.
\end{abstract}

Keywords: Exploitation. Donkey hide. Family farming system. Unit cost of production.

\section{RESUMO}

O estudo teve como objetivo estimar o custo de produção do jumento e contextualizar com a condição socioeconômica da região semiárida brasileira. Foi proposto um modelo de estudo no qual foram considerados os custos de manutenção e produção animal, admitindo que o rebanho já existisse na propriedade com utilização das instalações disponíveis. O ciclo de produção do jumento foi estimado em 36 meses, com rebanho inicial de 100 matrizes e cinco reprodutores. Para a estimativa de produção de forragem, foram consideradas pastagens nativas da região semiárida. Foi estimado o custo de produção do jumento em US\$258,00/ano. Entretanto, quando o jumento está integrado à unidade produtiva do segmento da agricultura familiar, esse animal deve ser considerado como ativo de produção (tração, carga e transporte). Diante da crescente demanda da pele de jumentos no mercado internacional, da ausência de políticas públicas de proteção e bem-estar desses animais, e mesmo considerando a possibilidade de integrá-los ao sistema de agricultura familiar, permanece a pergunta: quanto tempo vai levar até que os jumentos nordestinos sejam extintos? Estimar o custo unitário da produção de jumentos e considerá-los como um ativo essencial de produção na agricultura familiar pode ser um ponto de partida para diminuir seu abandono às consequências da exploração de pele.

Palavras-chave: Exploração. Pele de jumento. Agricultura familiar. Custo de produção.

Correspondence to:

Chiara Albano de Araujo Oliveira

Universidade Federal da Bahia, Escola de Medicina Veterinária

e Zootecnia

Avenida Adhemar de Barros, 500, Ondina

CEP: 40170-155, Salvador - BA

e-mail: oliveirachiara@gmail.com

Received: August 31, 2020

Approved: December 22, 2020
How to cite: Bittencourt TCBSC, Silva EM, Oliveira CAA. How much is a donkey worth?. Braz J Vet Res Anim Sci. 2021;58(special issue):e174335. https://doi.org/10.11606/ issn.1678-4456.bjvras.2021.174335

Donkeys (Equus asinus) arrived in Brazil with Portuguese colonizers and played an important role in the expansion of human populations, as well as the establishment of trade routes. In the colonial period, donkeys and mules were the 
only means of transporting goods and people between the coast and the interior of the country (Carneiro et al., 2018). Today these animals contribute to the subsistence of millions of people in less industrialized regions, such as the semi-arid region in northeast Brazil, where the Northeastern donkey is adapted to the severe climate conditions. However, since the second half of the $20^{\text {th }}$ century, the population of donkeys in Brazil suffered an abrupt reduction. The population of the Northeast region decreased by $7.4 \%$ from 2011 to 2012, representing one of the highest decreases in donkey herds reported (Instituto Brasileiro de Geografia e Estatística, 2013).

The increase in agricultural mechanization, the use of motorcycles, and the rural exodus have resulted in donkeys being abandoned on roads, causing accidents. To help minimize the problem, government authorities encouraged the slaughter of donkeys for the export of meat and its derivatives, mainly to Japan and Europe (Carneiro et al., 2018). Recently, the exportation of donkey hides to China has escalated the slaughter of the Northeastern donkey. In 2018, only one slaughterhouse exported 44,000 donkey hides, but the target is 200,000 donkey hides per year (personal communication).

Donkeys have been commercialized (mostly in the Northeastern region of Brazil) in an unsustainable exploratory way for hide exportation, in which an extremely low price is paid for the animal purchase. Some animals are captured on the roads, others acquired for prices between US $\$ 4.00$ to US $\$ 15.00$, and these values are added only by the cost of transportation to the slaughterhouse, which is estimated between US $\$ 10.00$ to US $\$ 75.00$ per animal. The transportation costs vary due to the distance in $\mathrm{km}$ between the place of acquisition of the animal and the slaughterhouse. Thus, for the business to be viable, the final price of the animal must be as low as possible. However, the exploitation exposes the Northeastern donkey to the risk of extinction (Carneiro et al., 2018; The Donkey Sanctuary, 2019). According to Camillo et al. (2018), the survival of donkey breeds and the possibility of increasing their numbers are related to the economic interest in the animal and its products. Yet, knowledge about donkey production systems, production rates, and production costs of the species is scarce.

Knowing the donkey production costs is the basis for the animal to be recognized as an essential asset, and, thus, reducing their abandonment and the consequences of hide exploitation. Therefore, this study aimed to estimate the donkey unit cost of production and contextualize it with the socio-economic condition of the Brazilian semiarid region. A major part of the northeastern region of Brazil is characterized by poor spatial and temporal distribution of rainfall, marked seasonality, and reduction in the amount of forage produced, especially in the dry season. Under natural and normal conditions of average rainfall that occurs in the areas of the northeastern hinterlands, forage production is scarce. On average, this production occurs for four months per year. Thus, providing adequate resource storage for the animals over eight months in a sustainable manner, from an economic, ecological, and social point of view, is the greatest obstacle to be overcome in animal production (Wander \& Martins, 2004).

The definition used in the present study for an extensive system of donkey production was based on a study carried out by Nobre ${ }^{1}$ (Unpublished data). In the model proposed in this study, the costs of maintenance and animal production were considered assuming that the herd already exists in the property and the use of available facilities.

The donkey production cycle has been estimated at 36 months, which is the time necessary for the animal to reach $100 \mathrm{~kg}$ of live weight. In this simulation, the parameters and production indices (Tables 1 and 2) proposed by Nobre ${ }^{1}$ (Unpublished data) were used. In this study, the initial herd consisted of 100 adult jennies (minimum and maximum age of 3 and 6 years, respectively) and 5 jacks (aged between 6 and 15 years). The expected age of females at first mating was defined as 36 months, and 48 months at first calving. The estimate for four years is that three births per female will occur. Considering the annual average mortality of $2.5 \%$ (young and adults), we calculated that there will be an average production of 66 animals every 16 months.

Table 1 - Technical assumptions of the physical model

\begin{tabular}{lcc}
\hline \multicolumn{1}{c}{ Herd size } & Number of animals & Equivalent UA ${ }^{1}$ \\
\hline $\begin{array}{l}\text { Matrices in } \\
\text { reproduction }\end{array}$ & 100 & 30 \\
$\begin{array}{l}\text { Female replacement } \\
\left(\mathbf{1 0 \% ) ^ { 2 }}\right.\end{array}$ & 10 & 22 \\
$\begin{array}{l}\text { Jacks } \\
\text { (2) }\end{array}$ & 5 & 1.9 \\
$\begin{array}{l}\text { Offspring } \\
\quad \text { up to } 12 \text { months } \\
\text { between } 12 \text { and 24 } \\
\text { months } \\
\text { between 24 and 36 } \\
\text { months }\end{array}$ & 70 & 9.8 \\
Total & 68 & 12.4 \\
\hline
\end{tabular}

${ }^{1}$ Animal unit (UA) $=450 \mathrm{~kg}$; ${ }^{2}$ herd data according to Nobre' (Unpublished data). 
Table 2 - Production indices, zootechnical parameters of the physical model, and animal production

\begin{tabular}{lc}
\hline Productive Indices $^{1}$ & \\
\hline Reproductive performance (\%) & 70 \\
Gestation length (months) & 12 \\
Interbirth interval (months) & 16 \\
Mortality breeding animals (annual) (\%) & 1.6 \\
Mortality rate of foals (annual) (\%) & 2.5 \\
Abortion rate (\%) & 1 \\
\hline Zootechnical parameter ${ }^{2}$ & 9 \\
\hline Weaning (months) & 15.5 \\
Average live weight at birth of males (kg) & 14.9 \\
Average live weight at birth of females (kg) & 65 \\
Live weight at 12 months (kg) & 82 \\
Live weight at 24 months (kg) & 100 \\
Live weight at 36 months (kg) & 140 \\
Live weight of adult females (kg) & 170 \\
Live weight of adult males (kg) & Quantity \\
\hline Annual production & 34 \\
\hline Males & 32 \\
Females & 66 \\
Total & \\
\hline Prodive in & \\
\hline
\end{tabular}

${ }^{1}$ Productive indices and ${ }^{2}$ Zootechnical parameters according to Nobre ${ }^{1}$ (Unpublished data).

According to Nobre ${ }^{1}$ (Unpublished data), for the estimation of forage production, the possibilities are variable according to several factors: availability of water, nature of soils, and types of soil and fodder, among others. After the herd stabilization period proposed for the study (Table 1) and considering the average annual consumption of 4.5 tons $(\mathrm{T})$ of green matter per year, it is necessary to produce $950 \mathrm{~T}$ of forage. Assuming that donkeys are reared in areas of native pastures, in semi-dense areas, with natural or non-natural clearings, and median occurrence of forage, the expected average forage production is $2.5 \mathrm{~T} / \mathrm{ha} /$ year. For this level of production, an area of 380 ha is necessary. If the animals are reared in cultivated pasture areas, an average production of $15 \mathrm{~T} / \mathrm{ha} /$ year is expected, which would reduce the area to 63.5 ha. According to Nobre $^{1}$ (Unpublished data), for the sustainability of the production system, the use of native and cultivated pasture is recommended.

According to Wander \& Martins (2004), the physical models of animal production are a simplification of reality. This simplification is necessary due to the difficulty of defining a priori conditions in such a diverse system. Many parameters would have to be considered, such as the technical-scientific and economic status, adoption of

Nobre, Fernando Viana. Plano de criação de jumentos: estudo de parâmetros zootécnicos do jumento nordestino. Universidade Federal do Rio Grande do Norte. Unpublished data; 2016.
Table 3 -Annual costs of maintenance and unit cost of production of stabilized donkey herd

\begin{tabular}{lc}
\multicolumn{1}{c}{ Acquisitions and expenses $^{1}$} & Annual Cost (US\$) $^{\mathbf{2}}$ \\
\hline Mineral supplement (MS) & 2138.00 \\
Hay & 2588.00 \\
Vaccines $^{3}$, vermifuge and drugs (VVD) & 975.00 \\
Fixed employee expenditure $^{4}$ (FEE) & 7619.00 \\
Temporary staff costs; 260 days/year $^{5}$ (TSC) & 3714.00 \\
Donkey Unit Cost of Production (DUCOP) $^{6}$ & 258.10 \\
\hline
\end{tabular}

${ }^{1}$ Calculations based on 91.2 UA (Table 1); ${ }^{2}$ Reference value dollars July 2020 ( $R \$ 5.35$ ); ${ }^{3}$ Vaccines: rabies and encephalomyelitis; ${ }^{4}$ Minimum wage plus charges (base July 2020); ${ }^{5}$ Day US\$ 14.00 (base July 2020); ${ }^{6}$ DUCOP: MS+Hay+VVD+FEE+TSC/ 66 - base on annual production (Table 2).

a single production system by all properties with similar environmental conditions (soil, climate, availability of quality water), and cultural and social components.

According to this study, the high production and maintenance annual costs of donkeys (Table 3) make it impossible to raise these animals for slaughter. The reproductive cycle of the donkey is long (Table 2), and the production of animals requires time and a significant economic investment. Donkey meat does not have an attractive price in the international market, which does not justify the investment in organized production. Around the world, donkey products, such as meat and milk, are secondary to the use of these animals for the transportation of people and cargo (Bennett \& Pfuderer, 2020). Besides, it is worth mentioning that the climatic conditions in the semi-arid regions can raise the production cost curve and should be considered in the future.

Considering that the conventional animal production system is not suitable for the species, which has social and welfare specificities, and that the international demand for the product (hide) is immediate and growing, the possibility of extinction of the Northeastern donkey and the absence of public policies that could guide the integration of the donkey into the traditional production systems that already exist should be reflected on. Furthermore, in some communities, donkeys are still used as working animals, and for carrying goods from the family property to fairs, and processing facilities of raw material, such as sisal fiber, manioc flour, and vegetables. In these establishments, the use of the donkey as a transport and working animal has been progressively replaced by mechanized transport. However, especially for the production of sisal fiber, the donkey is an essential tool. The sisal fiber manufactured products are considered agroecological, which should boost the sanitary management, welfare, and commercial value of donkeys.

For the assessment of donkey unit cost of production, the present study estimated an area of 64 to 380 ha with a 


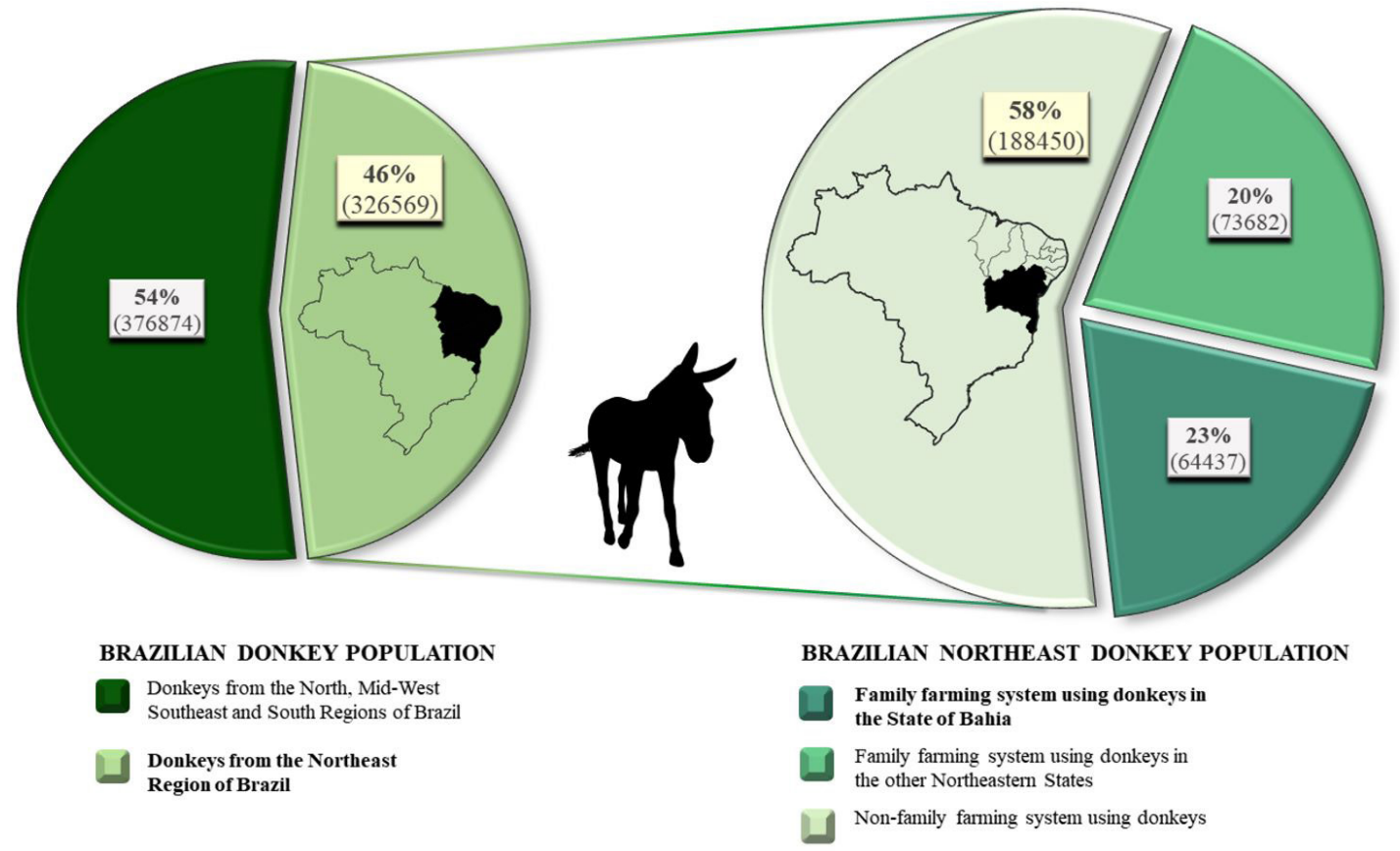

Figure 1 - Distribution of the donkey population in family and non-family farming systems in Brazil and the Northeast region (Instituto Brasileiro de Geografia e Estatística, 2019).

stable herd of 311 animals. However, considering small farms, categorized as a family farming system, in which the farm total area is between 10 ha and 70 ha, the production/breeding cost of the donkey could be higher. In those enterprises, where the donkey should be considered as a production asset and not knowing the value and production cost of the animal, the result may be the disposal or abandonment of the animal.

In reflection of the current problem for local vulnerable communities, it is worth considering the data from the Agricultural Census of the Instituto Brasileiro de Geografia e Estatística (2019) that show that most of the properties that raise donkeys are family farming in the Brazilian Northeast region (Figure 1). In this category, the enterprises are managed by the family, and in addition to the predominant use of family labor, production is diversified for self-consumption and surplus generation. Considering the donkey as part of a family farming implies that this animal is a production asset (draught, pack, and ridden), which should improve the productive and commercial value of donkeys.

In face of the growing demand for donkey hide in the international market, the absence of public policies for the protection and welfare of these animals, and even considering the possibility of integrating them into family farming systems, the following question must be asked: how long is going to take until Northeast donkeys are extinct?

Estimating the unit cost of donkey production and considering them as an essential production asset in family farming could be a starting point to diminish their abandonment in several communities and the consequences of hide exploitation.

\section{Conflict of Interest}

The authors declare there is no conflict of interests.

\section{Ethics Statement}

This article does not contain any studies with human participants or animals.

\section{Acknowledgements}

The authors thank to NGOs Frente Nacional de Defesa dos Jumentos, Fórum Nacional de Proteção e Defesa Animal, União Defensora dos Animais-Bicho Feliz and The Donkey Sanctuary.

\section{References}

Bennett R, Pfuderer S. The potential for new donkey farming systems to supply the growing demand for hides. Animals. 2020;10(4):718. http://dx.doi.org/10.3390/ani10040718. PMid:32326062.
Camillo F, Rota A, Biagini L, Tesi M, Fanelli D, Panzani D. The current situation and trend of donkey industry in Europe. J Equine Vet Sci. 2018;65:44-9. http://dx.doi. org/10.1016/j.jevs.2017.11.008. 
Carneiro GF, Lucena JEC, Barros OL. The current situation and trend of the donkey industry in South America. J Equine Vet Sci. 2018;65:106-10. http://dx.doi.org/10.1016/j. jevs.2018.03.007.

Instituto Brasileiro de Geografia e Estatística - IBGE. Produção da pecuária municipal 2012 [Internet]. Rio de Janeiro: IBGE; 2013. (vol. 40) [cited 2020 Aug 15]. Available from: https://biblioteca.ibge.gov.br/visualizacao/ periodicos/84/ppm_2012_v40_br.pdf.

Instituto Brasileiro de Geografia e Estatística - IBGE. Censo Agropecuário 2017: resultados definitivos [Internet]. Rio de Janeiro: IBGE/SIDRA; 2019 [cited 2020 Aug 15]. Available from: https://sidra.ibge.gov.br/pesquisa/censo-agropecuario/ censo-agropecuario-2017.
The Donkey Sanctuary. Under the skin: update on the global crisis for donkeys and the people who depend on them [Internet]. 2019 Nov [cited 2020 July 29]. Available from: https://www.thedonkeysanctuary.org.uk/sites/uk/ files/2019-12/under-the-skin-report-english-revised-2019. pdf.

Wander AE, Martins EC. Custos de produção de ovinos de corte no estado do Ceará. In: Anais do $42^{\circ}$ Congresso da Sociedade Brasileira de Economia e Sociologia Rural [Internet]; 2004; Cuiabá. Cuiabá: SOBER: UFMT; 2004. 20 p. [cited 2020 Aug 15]. Available from: http://www.alice. cnptia.embrapa.br/alice/handle/doc/534032.

Financial Support: None. 